UNIVERSITY

OF DEBRECEN

FACULTY OF

Health

NYÍREGYHÁZA

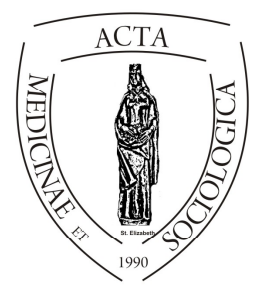

ACTA

MedSoc

VOLUME 7.

2016

\title{
Bulgarian School in Budapest - Past and Future Possibilities
}

\author{
Ralitsa Savova ${ }^{1}$, Andrea Toldi ${ }^{2}$ \\ 1. Faculty of Economics, University of West Hungary \\ 2. Faculty of Health, University of Debrecen
}

\begin{abstract}
The Bulgarian school in Budapest was the oldest Bulgarian public school abroad. During its existing almost a century - was established in 1918 and was closed in 2011, it was an emblematic symbol of the Bulgarian community in Hungary and the most important factor contributing to the preservation of the Bulgarian identity and the Bulgarian language there. An epitome of good political will between Bulgaria and Hungary, the lack of a school will be felt in the new political situation in the 21 st century, in which Bulgaria and Hungary are part of the European Union, and also in the increasingly developing economic and cultural relations between the two countries.
\end{abstract}

Keywords: local social welfare system, Bulgarian-Hungarian relationship, social policy, minority schools, education policy

DOI: $10.19055 / \mathrm{ams} .2016 .7 / 22-23 / 8$ 


\section{Historical Background of the Bulgarian School in Budapest}

\section{The establishment of the Bulgarian school}

The establishment of the Bulgarian school in Budapest in 1918 was determined by the final approval of the Bulgarian market gardening in the whole Hungary and in its capital, in the second decade of the $20^{\text {th }}$ century. The appearance of the Bulgarian market gardeners in nowadays Hungary started in the middle of the $19^{\text {th }}$ century, many decades before the official diplomatic relations between the two countries were established in $20^{\text {th }}$ century ${ }^{1}$. The purpose of their migration to the Hungarian Kingdom was a search for subsistence out of the late feudal and backward Ottoman Empire and also for markets of their production.

The first Bulgarian market gardeners ever came to Hungary in April 1865. They leased 75 acres of meadows to grow vegetables. They were five people at that time, but eight years later, in 1873 (till the middle of April), 18000 Bulgarian market gardeners passed the Danube, leased lands in the whole country and started to work on them. By the end of the $19^{\text {th }}$ century, only in Pest County (i.e. in a wide circle around the capital) Bulgarian market gardeners already worked in 61 settlements (Гюров 2001: 141, 144).

Their work was seasonal in the beginning - every year they came to the territory of the Hungarian Kingdom in early spring (St. Tryphon's Day, or Trifon Zarezan $^{2}$ ) and went back home in late autumn (after St. Demeter's Day, or St. Demetrius $^{3}$ ). Their temporary residence permits were traditionally issued for a fixed period - from the $1^{\text {st }}$ of February till $15^{\text {th }}$ of November (Гюров 2001:142). At that time the Bulgarians lived in ethnically closed compact groups ${ }^{4}$. The natural reason which united them was that they exercised the same craft - market gardening. In their home country Bulgaria most of them belonged to the same

\footnotetext{
${ }^{1}$ On $9^{\text {th }}$ of August 1920.

Source: Национален експортен портал България, http://export.government.bg/ianmsp/chujdi-pazari-spisak/hungary

2"The patron saint of gardeners ; and of vine growers in Bulgaria and Montenegro. It is thusappropriate in those countries that St. Tryphon's Day, or Trifon Zarezan, coincid es with the beginning of the pruning seasonin February ".appropriate in those countries that St. Tryphon's Day, or Trifon Zarezan, coincides with the beginning of the pruning seasonin February". http://encyclopedia2.thefreedictionary.com/St.+Tryphon's+Day

${ }^{3}$ Saint Demetrius of Thessaloniki, a patron of agriculture. His feast day is $26^{\text {th }}$ of October.

${ }^{4}$ Посолството на Унгария в София, Българите в Унгария.
} 
ethnographic area - the villages of Draganovo and Polikraishte ${ }^{5}$, the towns of Lyaskovets and Dolna Oryahovitsa ${ }^{6}$. Also all of them, without an exception were Orthodox Christians (Гюров 2001: 142). Another reason which united the market gardeners was the language barrier - at that time only few Bulgarians spoke fluently Hungarian.

During the First World War the free movement between the two countries became difficult and many Bulgarian families remained in Hungary with their children $^{7}$. They did not go back home to Bulgaria every year ${ }^{8}$. Many of them started to lease gardens for a longer period, others even bought lands, houses, and settled down in Hungary.

Gradually, within the Bulgarian community the need of establishing own institutions ripened. In 1914 in Budapest the Association of Ethnic Bulgarians in Hungary (In Hungarian: Magyarországi Bolgárok Egyesülete or in Bulgarian: Дружество на българите в Унгария), and in 1916- the Bulgarian Orthodox Parish were established. On $4^{\text {th }}$ of February 1917, with the contribution of Consulate General of Bulgaria, the Budapest Municipality gave an establishment permit for a primary school (Ватова 2001). It opened its doors on $25^{\text {th }}$ of February 1918 in Lónyay Street - the first home of the Association of Ethnic Bulgarians in Hungary where the Orthodox Parish and the chapel were set up as well ${ }^{9}$. The first name of the school was Bulgarian National School (Пейковска 2011). The school operated as primary school from 1918 till 1922, and as a seven grade school - from 1922 (Ватова 2001) .

Between 1935 and 1940, the school functioned at 13 Somogyi Béla Street in Budapest. Nowadays on that building there is a commemorative plaque to the former Bulgarian school showing the period when it was in function there ${ }^{10}$. Such plaque was erected in 1993 on the Lónyay building too, to commemorate the 75 th anniversary of its founding ${ }^{11}$.

The Bulgarian school in Budapest also established two branches - in 1923 a school and a chapel in Miskolc, and in 1954 a primary school in Pécs were established.

\footnotetext{
${ }^{5}$ Посолство на Унгария в София, Българите в Унгария.

${ }^{6} \mathrm{http}: / /$ emberijogok.kormany.hu/ethnic-bulgarians-in-hungary

${ }^{7}$ Bolgarok.hu

${ }^{8}$ Посолство на Унгария в София, Българите в Унгария. Списание „Европа 2001“, стр.18, бр.5, година XVII, 2010 г. http://euro2001.net/

${ }^{9} \mathrm{http}: / /$ www.bolgarok.hu/fileadmin/kepek/veszti/0702/veszti_4eves.pdf

${ }^{10}$ Budapest, District VIII, Somogyi Béla Street Nr 13 https://commons.wikimedia.org/wiki/File:Bulgarian_school_in_Budapest_Bp08_Somog yiBéla13.jpg

${ }^{11}$ Bolgarok.hu
} 
In the first years of its opening, the maintenance of the school in Budapest was implemented by the Bulgarian community which collected donations for a comprehensive support of the students. By the end of the Second World War the community gathered donations for heating as well, even for clothing and for the maintenance of poorer children ${ }^{12}$.

\section{During the socialist epoch}

After the Second World War the maintenance care was borne by the Bulgarian education ministry: it sent teachers, allocated funds to support the building, established a kindergarten in 1971.

Ten years after the end of the Second World War, the Bulgarian school changed its location twice. In 1954/55 it used four class rooms at 20 József Street 20, where 158 students attended the school (Гюров 2001). On $23^{\text {rd }}$ of March 1955, a representative of Hungarian Ministry of Foreign Affairs gave the secretary of the Bulgarian Embassy the keys of the building at 44 Bajza Street (Гюров 2001). Over a half century - since 1955 till its closing in 2011, the school could be found at that address, in the very prestigious VI district of the Hungarian capital. Provided by the Hungarian state, 44 Bajza Street became a real home of the Bulgarian school, because before its moving there, it had got only some rooms and a gym. After the moving to the monumental building at Bajza Street, the school became a boarding school.

During the socialist epoch the Bulgarian school in Budapest got two very high awards from the Bulgarian government. In 1967 - the award "Cyril and Methodius" II-nd grade ${ }^{13}$ and in 1982 - Order of the Red Banner of Labour ${ }^{14}$ (Гюров 2001). That period of time was successful for the Bulgarian school in Budapest but not for its branches - on $1^{\text {st }}$ of September 1968 the school in Pécs was closed, followed by the closing of the school in Miskolc in 1970.

In 1981 after the establishment of a high school class in the Bulgarian school, it was transformed into a Bulgarian - Hungarian language high school with a major: tour guiding ${ }^{15}$.

\footnotetext{
${ }^{12} \mathrm{http}: / /$ www.bolgarok.hu/fileadmin/kepek/veszti/0702/veszti_4eves.pdf

13 The Order "Cyril and Methodius" II-nd grade was awarde $\bar{d}$ at that time as an honour in the field of science, culture or painting.

${ }^{14}$ The Order of the Red Banner of Labour was awarded to Bulgarian and foreign citizens and labour collectives for outstanding achievements in the development of the national economy and achievements in public, social, scientific and cultural life of the country.

${ }^{15}$ Bolgarok.hu
} 


\section{After political system change}

In 1992 an agreement for joint maintenance of the school between the Bulgarian and the Hungarian Ministry of Education was signed. According to this agreement the school acquired the status of a state-owned Bulgarian-Hungarian secondary language school, keeping the Bulgarian character. This allowed the proceeding for its better integration in the Hungarian environment with the introduction of twelve grade training, culminating in matriculation exams, consistent with both the Bulgarian and Hungarian requirements for completion of secondary education. Since 1993 the school operated as a twelve grade school ${ }^{16}$.

It operated in accordance with the Bulgarian educational program. The school consisted of a kindergarten, a secondary school from first to eighth grade and a high school from first to fourth year ${ }^{17}$. Upon the successful completion of the school, the graduates received a Bulgarian diploma, translated into Hungarian language, which was recognized by Bulgaria and Hungary and did not need further legalization. Those students who would like to continue their education at colleges and universities in Hungary had the opportunity to take matriculation exams according to the Hungarian educational requirements. The resulting certificate of a Hungarian baccalaureate exam was an integral part of the Bulgarian diploma. The school provided good facilities - it was equipped with computer and language rooms, and supplied with qualified teachers and good training in foreign languages ${ }^{18}$.

In 1996, by Order № РД -14-60, issued on $11^{\text {th }}$ of June 1996 by the Minister of Education and Science, based on the Bulgarian National Education Act and the Agreement between the Ministry of Education and Science of Republic of Bulgaria and the Ministry of Culture and Education of Republic of Hungary, the Bulgarian kindergarten, the primary school and the high school were converted into a Bulgarian - Hungarian secondary language school which provided a kindergarten, a school with twelve regular education classes and an adjoining dormitory. In the Agreement, the Parties agreed the school to function as a joint Bulgarian-Hungarian public school and the agreement entered into force from the day of signing it on $29^{\text {th }}$ of September $1992^{19}$. The Bulgarian - Hungarian language secondary school in Budapest, was funded both with the subsidy from the budget of the Ministry of Education and Science of the Republic of Bulgaria and with financial assistance - subsidy from the Republic of Hungary, under a contract for sponsorship between the school and the Hungarian Ministry of Cul-

\footnotetext{
${ }^{16}$ Bolgarok.hu

${ }^{17}$ Bolgarok.hu

${ }^{18}$ Bolgarok.hu

${ }^{19}$ Доклад-Сметна палата на Република България 212.122.184.197/files/_bg/Dokladbulg-uchilishta07.doc
} 
ture and Education, according to Art. 6 of the Agreement concluded in 1992 between the Ministry of Education and Science of the Republic of Bulgaria and the Ministry of Culture and Education of the Republic of Hungary ${ }^{20}$.

The curriculum of the school was agreed with the Hungarian State. All the subjects were taught in Bulgarian language, only geography and history - in Hungarian. And at the completion of their secondary education the children received diplomas in two languages: Hungarian and Bulgarian. The Bulgarian community revivified the dormitory to the boarding school to teach the children who lived outside Budapest ${ }^{21}$.

The educational activity among the Bulgarians abroad in a sector of a school education in $2007^{22}$ was carried out in various forms:

- Bulgarian schools abroad

- Training at schools to the Bulgarian embassies abroad

- Training outside embassies (Saturday-Sunday schools, courses,

- Training in Bulgarian language at the schools of the host country

Then there were three Bulgarian state schools abroad - The Petar Beron Bulgarian secondary school, Prague, Czech Republic; The Hristo Botev Bulgarian secondary school, Bratislava, Slovak Republic and The Hristo Botev Bulgarian Hungarian secondary language school, Budapest, Hungary. The three Bulgarian schools were financed from funds from the budget of the Ministry of Education and Science, which was 544462 leva for $2006^{23}$ for The Hristo Botev Bulgarian-Hungarian secondary school in Budapest. The activity of these schools was organized to the applied Bulgarian regulations. Students who attend these schools are granted Bulgarian documents for completing grade and level of education. Continuing their education at a school in Bulgaria, Bulgarian students from state schools abroad did not take exams ${ }^{24}$.

20 Доклад-Сметна палата на Република България 212.122.184.197/files/_bg/Dokladbulg-uchilishta07.doc

${ }^{21}$ Бахчеванов, Светозар , Българите в Унгария тачат родните традиции. Вестник „Стандарт“, 30. 08. 2010

${ }_{22}^{22}$ Bulgaria is EU member state since: 1 January 2007

${ }^{23}$ In 2006, 1 EUR $=1.95583$ BGN :

https://money.bg/archive/fiksirani-i-plavashti-valutni-kursove.htm

${ }^{24}$ Отговор на въпрос към министър Даниел Вълчев от народния представител Иво Атанасов, относно : Образователните стандарти в българските училища в чужбина. Писмени отговори на актуални въпроси и запитвания. Стенографски дневници, 04.05.2007, Народно събрание на Република България. http://www.parliament.bg/pub/StenD/DOC190209-008.pdf 
In 2011 the school was closed. The order for its closure was РД 09-1306/ 16.09.20112. The take-over record was issued on $25^{\text {th }}$ of September 2011. The storage of the documentation is held by The Pencho P. Slaveykov First Secondary School, Sofia ${ }^{25}$. After the closure of The Hristo Botev Bulgarian-Hungarian secondary language school, to 44 Bajza street moved the seat of the Bulgarian self-government (In Hungarian: Bolgár Országos Önkormányzatand or in Bulgarian: Българско републиканско самоуправление), established 1995, and its new educational bodies - the Bulgarian school for native language (In Hungarian: Bolgár Nyelvoktató Nemzetiségi Iskola or in Bulgarian: Българско училище за роден език), established in 2004, and the Bulgarian minority bilingual kindergarten (In Hungarian: Bolgár Kétnyelvü Nemzetiségi Óvoda or in Bulgarian: Българска двуезична малиинствена детска градина), established in $2008^{26}$. After lengthy negotiations the Bulgarian self - government contracted for receiving the building from the Hungarian Treasury, linked to strict conditions of use, and to ensure the maintenance of this building. The contract foresaw an annual amount of 5.5 million HUF, to be paid as a tax, but also there was an option the money to be invested in the reconstruction and renovation of the building. 27

Since 2011 the closure of Bulgarian school has been a fact. There are many reasons about it:

Material problems and lack of students:

The lack of resources, the reduction of funds for its maintenance, and for the building maintenance too. According to the Bulgarian Ministry of Education, the maintenance of the schools abroad was very expensive while the number of the students decreased ${ }^{28}$.

In the recent years of the existing of the school, there has been a withdrawal from this school, according to Dancso Muszev, the chair of the Bulgarian selfgovernment in Hungary. Although the Bulgarian community in Budapest was

\footnotetext{
25 МИНИСТЕРСТВО НА ОБРАЗОВАНИЕТО, МЛАДЕЖТА И НАУКАТА, РЕГИОНАЛЕН ИНСПЕКТОРАТ ПО ОБРАЗОВАНИЕТО СОФИЯ - ГРАД, РЕГИСТЬР НА ЗАКРИТИТЕ И ПРЕОБРАЗУВАНИ УЧИЛИЩАwww.rio-sofiagrad.com/web_folders/...files/registyr_zakriti.doc

26 Димитрова, Коянка(2015), Среща на председателя на ДАБЧ със сънародниците ни в Будапеща, 12.11.2015

${ }^{27} \mathrm{http} / /$ www.bolgarok.hu/fileadmin/kepek/veszti2011/1110/veszti1110_kisfelbontas.pdf

${ }^{28}$ Ханджиев, Радко (2010) Пак заради имоти ли..... Ликвидират училище „Христо Ботев“" в Унгария. В-к „Дума“"http://duma.bg/node/7740
} 
significant, there were not so many kids who were trained in the school - in 2010 only 20 students attended the school, he added ${ }^{29}$.

Human factor:

The teachers from Bulgaria were seconded in Budapest for a period of 2-3 years which was not enough to finish even one complete high school course of teaching $^{30}$. According to Muszev, the Bulgarian teachers had poor contacts with the Hungarian environment. His suggestion about managing the school issue in 2010 was the school to pass the Hungarian bilingual educational system of national and ethnic minorirties: half of the subjects to be taught in Hungarian and the other half - in Bulgarian. This would require no more than 4-5 teachers from Bulgaria and would optimize the means of the Bulgarian side for textbooks, manuals and trips ${ }^{31}$. There was no reply from the Bulgarian Ministry of Education to this suggestion, we guess probably because if the half of the subjects will be taught in Hungarian, the school would lose its Bulgarian character.

Assimilation:

According to Adriana Petkova Papadopulos, a representative of the leadership of the Bulgarian Cultural Forum in Budapest, "the suspension of the activities of the school means two things: first, what was done that is to preserve the Bulgarian identity, language and culture in Hungary was not enough, to resist consciously of the process of assimilation; secondly, that the local organizations and foundations did not reach consistency and awareness to promote and to support the training at the school" (Пападопулос 2015). Thanks to The Hristo Botev Bulgarian-Hungarian secondary school in Budapest, which was closed in 2011, there are still families of former gardeners in that fourth generation, born in Hungary, who speak, read and write very good Bulgarian language (Пападопулос 2015). The Bulgarian school in Budapest mastered not only the native language of the students." It taught them patriotism, it thought them to be Bulgarians in Hungary, Bulgarians in Europe, Bulgarians everywhere", said Dancso Muszev².

The Bulgarian school was a bridge of the ethnic Bulgarian students in Budapest to the homeland Bulgaria. Due to the new political environment and to the ex-

\footnotetext{
${ }^{29}$ Ханджиев, Радко (2010)

${ }^{30}$ Ханджиев, Радко (2010)

${ }^{31}$ Ханджиев, Радко (2010)

32 Ханджиев, Радко (2010) Пак заради имоти ли..... Ликвидират училище „Христо Ботев“" в Унгария. $B$-к ,Дума“

http://duma.bg/node/7740
} 
pansion of the economic and cultural relations between Bulgaria and Hungary within the EU, the school could prepare future specialists in the cultural, political, trade and in the tourism sphere, who can speak Bulgarian and Hungarian fluently. The lack of the school is yet to be felt among the new Bulgarian migrants to Budapest who would like their children to live in a multicultural surrounding but to preserve their native language as well.

\section{Justification for the application of the LOSS model}

According to the 2001 census of the Bulgarian population under the age of 14 was less than one hundred prior to the closing the Bulgarian school in Budapest. The age pyramid of the Bulgarians was increasing at the top and the closure of the school could be justified by the low level of ,demand”. Using the LOSS (Local Organization of Social Services) model (Bódi 2014), which was adopted as a model in the work of the Hungarian Parliament's Committee of Inquiry to reveal the causes of the school closing in 2013 (Hungarian Parliament, "The Causes of Kindergarten and School Closures of the Examining Committee" in 2003), demographic factors could also be among the causes of closing the school. ${ }^{33}$

Today, however, using the census data recorded in the year of the closure as a base, the number individuals with Bulgarian nationality has had a huge increase $(223 \%)$, compared to the data of 2001. Additionally the number under the age of 14 is now over three hundred.

Following the supply and demand analysis method of the LOSS model it can be demonstrated that the possibility of the re-opening of a Bulgarian national school with a full curriculum would be required given that the number of those in the Bulgarian community is growing. In addition, this small community, which has been educated above the national average, and with the reintroduction of the school would continue to inherit the mother tongue and identity as it did in the past.

The education in Bulgarian has always been constant in Hungary, either in a grassroots form in the previous century, or in a top-down form after the Second

\footnotetext{
33 Method sources of the LOSS: Bódi, F. \& Fekete, A. (2012) Changes in supply and demand in elementary education 1988-2009. In (Eds) Bódi, F. \& Fábián, G. \& Lawson, R. T. Local Organization of Social Services in Hungary (Crises - Reactions - Changes) Europäischer Hochschulverlag GmbH \& Co. KG, Bremen, pp 268-287., as well as, Balázsi, I. \& Bódi, F.(2012) School performance school reorganization. In (Eds) Bódi, F. \& Fábián, G. \& Lawson, R. T. Local Organization of Social Services in Hungary (Crises - Reactions - Changes) Europäischer Hochschulverlag GmbH \& Co. KG, Bremen, pp 288-317.
} 
World War. The Hungarian society has always profited from this human investment, as both the economic activity and the employment rate of the Bulgarian minority were significantly higher than that of the majority of the Hungarian society.

\section{The application of the LOSS model}

Up to about 1990 the majority of the Bulgarians living in Hungary were the descendants of the market gardeners who migrated to Hungary between the Conciliation and World War II. However, a new migration wave occured more recently. According to the 2001 census, $42 \%$ of the Bulgarian minority were born abroad, and of that $42 \%$ almost all (91\%) were born in Bulgaria (Toth - Vékás 2004). They are primarily first-generation immigrants who have studied, found a job here and have married a Hungarian. This number will certainly grow in the near future, due to Bulgaria joining the European Union in 2007.

\section{The demand side - the change in the number of the Bulgarian nationality}

\section{The definition of the Bulgarian nationality}

It should be taken into consideration that the present concept of nationality and the national categories and ethnic definitions derived from it were not used before 1990. Consequently the analysis of long data sequences would not be valid as the data are not comparable. Comparisons therefore can only be made from 1990 onward. Using strict criteria and specific definitions the two most recent census data can be compared.

After 2001 census a new methodology has been applied. While the 1990 census contained only categories like nationality, mother tongue and the spoken language, in 2001 new categories like minority cultural ties and languages spoken in the family and friend circle were included (Vékás 2003 237). Bulgarians, who live in Hungary, have two bounds, one Bulgarian and one Hungarian.

\section{An increasing number of Bulgarian nationality in Hungary}

Census data after the transition confirm that the number of the Bulgarians has increased (Table 1.), however, it is still not significant considering that an estimated two million Bulgarians have left Bulgaria in the past two decades (Christova-Balkanska 2010) .

At the same time, analytical sources report that similarly to the Poles, Armenians, Romanians, Rusyns, Serbs, Ukrainians and Germans, more than one 
fourth of people belonging to the Bulgarian community are not Hungarian citizens any more (Mayer 2005 177).

\section{The location of the Bulgarians in Hungary}

Nearly one-third of people with roots in Bulgarian cultural values live in the capital Budapest, and another one third live in other cities. Given these statistics it can be concluded that the Bulgarians are the most urban nationality in Hungary. This might be the result of the historical precedent that a vast majority of market gardeners live in big cities, or in their suburbs or agglomeration (e.g.: Budapest, Csepel, Zugló, Halásztelek, Pécs and within it Bolgárkert, Miskolc and within it Bolgárkert and the neighborhood Felsőzsolca). Another potential explanation is that the new immigrants found jobs mainly in Budapest, which influenced their settling down in Hungary.

\section{Changes in the age-composition of the Bulgarian nationality}

\begin{tabular}{|l|c|c|c|c|}
\hline 1930 & 1960 & 1990 & 2001 & 2011 \\
\hline \multicolumn{5}{|c|}{ man / } \\
\hline 2429 & 1399 & 751 & 651 & 1377 \\
\hline \multicolumn{5}{|c|}{ woman / } \\
\hline 387 & 727 & 619 & 648 & 1522 \\
\hline \multicolumn{5}{|c|}{ total / } \\
\hline 2816 & 2126 & 1370 & 1299 & 2899 \\
\hline
\end{tabular}

Source: Hungarian Central Statistical Office (KSH) Census 2011 (9. Nationalities Data)

1.Change of numbers of the Bulgarian nationality between 1930 and 2011 in Hungary (according to native language and gender)

After the millennium the relatively younger age structure of those with Bulgarian nationality (the proportion of the population between the age of 15-39 is approximately $31 \%$, see Table 2 .), is associated with the young age of a new generation of settlers whose majority came from the mother country. As early as the turn of the millennium, together with the Bulgarians a favorable age structure (younger age pyramid) (the percent of the15-39 year old population ) characterizes the Ukrainians and Romanians (44-44\%), Armenians (41\%), Greeks (39\%), Rusyns (38\%), Serbs (37\%) and Poles (32\%). Conversely, age pyramid of the Slovakians, Slovenians, Croatians, and Germans can typically be characterized as one that is bigger at the top (Dobos 2009 67). 


\begin{tabular}{|c|c|c|c|c|c|c|c|c|c|}
\hline \multirow{2}{*}{-14} & \multirow{2}{*}{$15-39$} & \multirow{2}{*}{$40-59$} & \multirow{2}{*}{$60-$} & \multirow{2}{*}{ Total } & -14 & $15-39$ & $40-59$ & $60-$ & Total \\
\hline & & & & & \multicolumn{5}{|c|}{ distribution, percent } \\
\hline \multicolumn{10}{|c|}{1930} \\
\hline 237 & 2051 & 430 & 98 & 2816 & 8.4 & 72.8 & 15.3 & 3.5 & 100.0 \\
\hline \multicolumn{10}{|c|}{1990} \\
\hline 97 & 433 & 391 & 449 & 1370 & 7.1 & 31.6 & 28.5 & 32.8 & 100.0 \\
\hline \multicolumn{10}{|c|}{2001} \\
\hline 84 & 400 & 462 & 353 & 1299 & 6.5 & 30.8 & 35.6 & 27.2 & 100.0 \\
\hline \multicolumn{10}{|c|}{2011} \\
\hline 322 & 897 & 883 & 797 & 2899 & 11.1 & 30.9 & 30.5 & 27.5 & 100.0 \\
\hline
\end{tabular}

Source: Hungarian Central Statistical Office (KSH) Census 2011 (9. Nationalities Data)

2. Age distribution of the Bulgarian nationality (according to native language) in Hungary

Compared to the majority population, the Bulgarians living in Hungary have an older age pyramid (The percentage of the Hungarian population under the age of 14 is higher, $14.3 \%$ ), however, they are significantly younger compared to other larger nationalities (Slovakian, German). For the future of the Bulgarians it might be an important factor that their population is getting younger, although further data collection from the Immigration Office is necessary. Table 2 shows, that 1299 people declared themselves as Bulgarian in 2001. This number increased more than two-fold, to 2899 , by 2011. The number of children under the age of 14 doubled from 84 to 322 , that is it increased from $6.5 \%$ to $11.1 \%$.

\section{The supply side - the impact of the national school to the Bulgarian nationality}

Educational data and economic activity of the Bulgarians compared to other nationalities and to the Hungarians

The following comparison reflects the results of the native Bulgarian educational system of the era operating in the balanced supply-demand model.

In Hungary, according to the 2001 census, the most educated nationality was the Bulgarian, followed by Armenian, Ruthenian and the Polish communities (Mayer 2004). 
Calculated from the 2011 census data, the Bulgarians are still highly educated. In terms of the 15-year-old and older population only $4 \%$ of the Bulgarian people completed less than 8 classes of the elementary school. It is similar to the percentage of the majority society, where only $5 \%$ of the Hungarians (only the Hungarians without the minorities) are poorly educated. However, taking the university and college graduates into consideration, 31\% of the Bulgarians graduated, while $17 \%$ of the Hungarians have a university degree. Maturity examination is the highest educational level for $31 \%$ of the Bulgarians, while this percentage is $21 \%$ for the Hungarians. ${ }^{34}$

The Bulgarians are the most educated minority in Hungary, and more educated than the majority society. Its reason might be: (1) they developed their own educational system from kindergarten to university very early, over one hundred years ago. Unfortunately by today there is only one kindergarten and a Sunday school in Budapest where Bulgarian language is taught and two university institutes of Slavic Philology, one in Budapest - at ELTE (Institute of Slavonic and Baltic Philology) and one in Szeged - at University of Szeged (Institute of Slavic Philology). (2) The majority of the new migration might already be highly educated. They work in the management and in research institutions of global companies or in big business centres. The high educational level of the Bulgarians may be in connection with the metropolitan existence, since the percentage of people with college or university grade is higher in the majority society in the urban population, especially in the population of the capital. (Budapest:28,9\%, county capitals: $25 \%$, national average: $15 \%$, in the population of small towns only $10 \%$ of the population has a degree) $)^{35}$.

\section{Conclusion}

There is a chance for the Bulgarian school to the restart as the number of the Bulgarian population and within it the number of the school-aged children is increasing. The Bulgarians in Hungary typically live in cities, with the majority settled in Budapest. The closed school would certainly be able to operate costeffectively. Consequently the examination of the restart of the Bulgarian school in Budapest would be advisable. LOSS methodology could be a good research tool in this process.

\footnotetext{
${ }^{34} \mathrm{http}: / /$ www.ksh.hu/nepszamlalas/iskolazottsag_sb

${ }^{35} \mathrm{http}: / /$ www.ksh.hu/nepszamlalas/iskolazottsag_sb
} 


\section{References}

1. Ватова, П. 2001: Корените и короната. Списание „Хемус“-между емблемите на малцинството и белезите на приобщаването. Будапеща. Българско реепубликанско самоуправление. Будапеща, 2001

2. Гюров, А. 2001: Единадесетвековно българско присъствие в Унгария. Будапеща, 2001 (Издава се с подкрепата на Българското републиканско самоуправление).

3. Пападопулос, А. 2015: Съвременната българска общност в Унгария и нейната идентичност в периода на промените (от началото на 90-те години до наши дни). „Научни перспективи на съвременната българистика "Редактор: Ищван Лукач, издател: : Български културен форум, Будапеща \& Катедра „Славянска филология“, Университет „Л.Йотвьош“, Будапеща \& Българско национално самоуправление, Кечкемет, 2015

4. Пенковска, П. 2011: Българското училище в Будапеща (1918 - 1936). Социално -антропологически анализ на неговата главна книга. Списание „Български фолклор“ 2011, кн. 1

5. Balázsi, I. \& Bódi, F. (2012) School performance school reorganization. In (eds) Bódi, F. \& Fábián, G. \& Lawson, R. T. (2012) Local Organization of Social Services in Hungary (Crises - Reactions - Changes) Europäischer Hochschulverlag GmbH \& Co. KG, Bremen, pp 288-317.

6. Bódi, F. (20014) Toward a dynamic theory of Local Organization of Social Services (LOSS) functioning. In. Bódi, F. \& Fábián, G. \& Fónai, M. \& Kurkinen, J. \& Lawson, R. T \& Pietiläinen, H. Access to Services in Rural Areas: A Comparison of Finland and Hungary. Europäischer Hochschulverlag GmbH \& Co. KG, Bremen, p. 315, pp. 4-26.

7. Bódi, F. \& Fábián, G. \& Fónai, M. \& Kurkinen, J. \& Lawson, R. T \& Pietiläinen, H. (2014) Access to Services in Rural Areas: A Comparison of Finland and Hungary. Europäischer Hochschulverlag GmbH \& Co. KG, Bremen, p. 315

8. Bódi, F. \& Fábián, G. \& Lawson, R. T. (2012) Local Organization of Social Services in Hungary (Crises - Reactions - Changes) Europäischer Hochschulverlag GmbH \& Co. KG, Bremen, p. 476

9. Bódi, F. \& Fekete, A. (2012) Changes in supply and demand in elementary education 1988-2009. In (eds) Bódi, F. \& Fábián, G. \& Lawson, R. T. Local Organization of Social Services in Hungary (Crises - Reactions - Changes) Europäischer Hochschulverlag GmbH \& Co. KG, Bremen, pp 268-287. 
10. Christova-Balkanska, Iskra (2010) Foreign Direct Investment (FDI) and Remittances from the Bulgarian Labor Migration. In Christova-Balkanska, Iskra (ed) Sustainable Development and Diversity in Bulgaria. Institute of Economics at Bulgarian Academic of Sciences. Sofia. pp. 179-196.

11. Dobos Balázs (2009) A magyarországi kisebbségpolitika szakpolitikai elemzése a kisebbségi törvény példája. [The Policy Analysis of the Minority Policy in Hungary - The Example of the Minority Act.] Budapest Corvinus Egyetem, Társadalomtudományi Kar, Politikatudományi Intézet, PhD értekezés. [Corvinus University of Budapest, Faculty of Social Science, Institute of Political Science, Ph.D. Thesis].

12. Mayer Éva szerk. (2004) Kisebbségek Magyarországon 2002-2003. [Minorities in Hungary 2002-2003] Nemzeti és Etnikai Kisebbségi Hivatal, Budapest. [Office for National and Ethnic Minorities, Budapest]

13. Mayer Éva szerk. (2005) Kisebbségek Magyarországon 2004-2005. [Minorities in Hungary 2004-2005] Nemzeti és Etnikai Kisebbségi Hivatal, Budapest. [Office for National and Ethnic Minorities, Budapest]

14. Tóth Ágnes - Vékás János (2004) Mit hoz a jövő?[What will the Future bring?] Kisebbségkutatás, 4. pp. 540-553.

15. Vékás János (2003) Statisztikai adatok az 1980-2001. évi népszámlálások összehasonlító elemzéséhez. [Statistical Data for Comparative Analysis of Censuses 1980 and 2001] In: Kovács, Nóra \& Szarka, László (szerk.) Tér és terep. Tanulmányok az etnicitás és az identitás kérdésköréből [Studies about Ethnicity and Identity] II. Akadémiai Kiadó, Budapest. pp. 237-251.

\section{Data Sources}

1. Népszámlálás 2011, 9. Nemzetiségi adatok, [Census 2011, No 9 Data of the Nationalities] KSH [Hungarian Central Statistical Office], Budapest 2014.

2. European Commission, Joint Research Center: List of Bulgarian Schools Abroad 2015/2016 year:

3. http://drdsi.jrc.ec. europa.eu/dataset/list-of-bulgarian-schools-abroad-20152016-year

Authors

Ralitsa Savova, PhD. candidate at Faculty of Economics, University of West Hungary, HU-9400 Sopron, Erzsébet str.9 9 $\neg$ savova@abv.bg

trainee, Centre for Social Sciences, Institute for Political Science, Hungarian Academy of Sciences. Budapest, Országház str. 30 ralitsa.savova@tk.mta.hu

Andrea Toldi, master lecturer at Faculty of Health, University of Debrecen, 4400-Hungary, Nyíregyháza, Sóstói str. 2-4., toldine.andrea@foh.unideb.hu 
